\section{Japan’s “Top Global University” Project}

\section{Yukiko Shimmi and Akiyoshi Yonezawa}

Yukiko Shimmi is assistant professor at Hitotsubashi University, Tokyo, Japan. E-mail: yshimmi@gmail.com. Akiyoshi Yonezawa is associate professor at Nagoya University, Japan. E-mail: yonezawa@gsid. nagoya-u.ac.jp.

Th September 20I4, the Ministry of Education, Culture, 1 Sports, Science and Technology in Japan (MEXT) listed 37 Japanese universities selected to the "Top Global University" project. These universities will receive governmental funding for up to Io years to improve their global competitiveness or to lead the internationalization of Japanese universities through the university reform (e.g., governance, management, structure, curriculum, and admission). Although the government's support for the internationalization of Japanese universities is essential, there are some concerns regarding the current project: such as, micromanagement of the government on the university reform, isomorphic standardization of the internationalization approach, and the widening gap among universities.

\section{The Characteristics of the Top Global University PROJECT}

The MEXT's Top Global University Project consists of two categories. Thirteen large research universities were selected to the status of Type-A institutions, which particularly focuses on the improvement of universities' globalization and their presence in the top Ioo of the world university rankings. The government clearly referred to the world university ranking as one of the numerical goals for the Type-A institutions. The Type-A institutions included all seven former imperial universities, four other national universities, and two prestigious private universities. They will receive 500 million Japanese yen (approximately US\$4.3 million) annually for up to Io years. Twenty-four universities were selected to the Type-B institutions, which will lead to the internationalization of Japanese higher education by leveraging their strength. The Type-B institutions included Io national, 2 local public, and I2 private universities. They will receive 200 to 300 million Japanese yen (approximately US\$I.7 to 2.5 million) annually for up to ro years.

Compared to the universities' total budget and some excellence initiatives in other countries, the amount of funding of the current project is not large. Unlike some other excellence initiatives, the current funding is not directly allocated for research activities, but rather for the enhancement of the international presence of the universities through the internationalization and reform of governance, management, and personnel policies to fit the global competition. Chosen universities could also use their status to attract domestic and international students as well as other stakeholders, by arguing that they are among a few universities selected as models of international universities by the national government.

\section{Plans for Selection and Implementation}

Each university had to submit a strategic plan, in which the universities outlined how they planned to achieve the internationalization and the university reform, based on their own strengths and resources. For example, Nagoya University, a top national university, submitted a plan to become "Asian university-hub for developing a sustainable world in the 2ist century" and launched satellite campuses in several Asian countries, to offer doctoral programs to the future national leaders. Keio University, a top private university, submitted a plan to strengthen its practice-oriented research, through the university-industry linkage.

\section{Compared to the universities' total bud- get and some excellence initiatives in other countries, the amount of funding of the current project is not large.}

The proposed activities in the plans of the selected universities, however, mostly resemble each another. Most of the universities referred to the internationalization of various educational aspects: providing interdisciplinary courses, joint-degree programs, and English-taught courses; instituting admission reforms by utilizing external language tests and research functions; internationally promoting international research collaboration, fostering universityindustry cooperation, developing international networks, and leveraging overseas research hubs; and other activities, such as faculty and staff development for internationalization.

These similarities occurred partly because the government requested the applying universities to fill a form that exemplifies the main activities. They were requested to report their current situation and future projection based on about 40 performance indicators. Adding to the typical indicators related to internationalization (e.g., the numbers of international students, exchange students who study abroad, institutional international agreements, and foreign faculty members), the universities were also required to re- 
port on various internationally-related activities (e.g., providing international residence halls, offering courses and degree programs in foreign languages, providing various Japanese-language courses, introducing Grade Point Average systems, making syllabi available in English, providing university information in foreign languages, and conducting admissions that are convenient for potential applicants overseas). In addition, some indicators were not relevant to internationalization but were relevant to a wider university reform-such as, the degree to which implementing the achievement-based salary system, the tenure-track system, and the evaluation system aligned with international standards.

\section{SOME Concerns}

This project can be a strong support for making these universities more internationally competitive. From the viewpoint of taxpayers, it must be reasonable that the government should monitor the progress of the publicly funded project with clear performance indicators. However, there are also some concerns regarding the consequences of this elaborately designed project.

This project may lead to an inefficient micromanagement of leading universities that need strong independence in nature. In principle, the current project appears to respect the importance of the universities' autonomous decisions, by agreeing on a strategic plan that is based on their mission and profiles. However, through the prescribed multiple indicators with rigorous monitoring and assessment for a long period, the universities may loose flexibility in their institutional decisions.

The prescribed indicators may lead to a similar standardization in the approach to internationalization, espe- cially among the top-research universities selected as "TypeA." Most of the indicators requested from the government are numerical, making it easy to compare one university to another and often emulating the indicators used for international university rankings.

In addition, another part of the current project could be a problem among Japanese universities. Including the current funding, a limited number of universities - mainly, prestigious large-scale comprehensive universities-have continuously received government's competitive funds for internationalization. While these universities have gradually developed internal systems and administrative capacities for the university reform and internationalization, the other universities have been left out. In parallel with this Top Global University project, the government is guiding a discussion on functional diversification and on the restructuration of the whole education system. Although it is difficult for the government to provide funds for all the universities to become "world-class" or to be internationalized, it is undesirable to leave the majority of students of this country out of the international learning environment.

While there are some potential concerns, this project will provide ideas and ways to achieve the internationalization and the university reform for both the selected and nonselected universities. The plans of the universities and the selection results are accessible online, and the interim and final reports by the universities will be also published online in Japanese and partly also in English. With the transparency of the whole selection and evaluation processes of the current project, the government and universities should make further efforts in the dissemination of good practices of internationalization reforms.

\section{NEW PUBLICATIONS}

American Association of University Professors. Policy Documents and Reports, 11th Edition. Baltimore: Johns Hopkins University Press, 2015.408 pp. \$49.95 (hb). ISBN 9781-4214-1637-3.

This volume contains official statements and position papers of the American Association of University Professors, the organization representing the US academic profession. Among the themes discussed are academic freedom, the evaluation of faculty members, faculty work, intellectual property and copyright, collective bargaining, discrimination, and others.
Arabljeradmand, Ali, et al. An Introduction to Internationalization of Higher Education: Essential Topics. Lanham, MD: University Press of America, 2015. 132 pp. (pb). ISBN 978-0-7618-6470-7. Web site: www.roman. com.

This book, by a group of Iranian academics, provides a general discussion of higher education internationalization based on the international literature on the topic. There is no discussion of the situation in Iran itself.

Blumenstyk, Goldie. American Higher Education in Crisis?: What Everyone Needs to Know. New York: Oxford University Press, 2015. 196 pp. \$16.95 (pb). ISBN 978-0-19-
937408-3. Web site: www.oup.com.

A short, clearly written broad analysis of the key issues facing American higher education by a senior writer for the Chronicle of Higher Education, this volume discusses such key themes as costs and debt, the changing student population, and leadership pressures. The book concludes with discussion of future trends such as MOOCs, "big data," and other key themes.

Crow, Michael M., and William B. Dabars. Designing the New American University. Baltimore: Johns Hopkins University Press, 2015. 344 pp. \$34.95 (hb). ISBN 978-1-42141723-3. Web site: www. press.jhu.edu. 